\title{
LÖYTŸ̈-VERBIN KONSTRUKTIOIDEN YHTEYDESSÄ ESIINTYVÄ SUBJEKTIN SIJANVAIHTELU
}

\author{
Rodolfo Basile ${ }^{\mathrm{a}, \mathrm{b}}$, Ilmari Ivaska ${ }^{\mathrm{b}}$ \\ ${ }^{a}$ Tarton yliopisto, EE \\ ${ }^{b}$ Turun yliopisto, FI \\ rodolfo.basile@ut.ee,ilmari.ivaska@utu.fi
}

\begin{abstract}
Abstrakti. Artikkeli tarkastelee löytyä-verbin konstruktioiden nominatiivi- ja partitiivisubjektin vaihtelua. Aineistona on korpuksista poimittu 779 havainnon satunnaisotos, jota tarkastellaan sekä kvantitatiivisesti tilastollisin menetelmin että kvalitatiivisesta näkökulmasta. Tutkimus pyrkii selvittämään, mitkä muuttujat vaikuttavat löytyä-verbin sisältävien lauseiden subjektien sijanvalintaan. Valikoidut muuttujat ovat subjektin luku, subjektin jaollisuus, subjektin sanaluokka, sanajärjestys, aikamuoto, subjektin ja verbin välinen kongruenssi sekä subjektin lemma, joka toimii satunnaismuuttujana. Regressioanalyysin keinoin subjektin sijanvalintaa ennustetaan mainittujen muuttujien ja niiden välisten vuorovaikutussuhteiden avulla. Laadullisessa analyysissa käsitellään myös näiden morfosyntaktisten ja semanttisten seikkojen vaikutusta lauseen eksistentiaalisuuden sekä subjektin kvantiteetin ja definiittisyyden tulkintaan.
\end{abstract}

Avainsanat: subjektin sijanvalinta, partitiivi, konstruktiot, morfosyntaksi, regressioanalyysi, määrällinen tutkimus, korpusmenetelmät, suomen kieli

DOI: https://doi.org/10.12697/jeful.2021.12.1.01

\section{Johdanto}

Viime aikoina kielitieteessä on keskusteltu usein nominatiivi- ja partitiivisubjektin välisestä vaihtelusta. Sitä on tutkittu esimerkiksi typologian (Luraghi \& Kittilä 2014) ja murteiden (Lindström 2017) näkökulmista. Slaavilaisissa kielissä, kuten puolassa (Blaszczak 2009) tai venäjässä, kyseinen vaihtelu tapahtuu nominatiivin ja genetiivin välillä, erityisesti kun verbi on kielteisessä muodossa (Blaszczak 2012, Seržant 2014, Partee \& Borschev 2008): tämä ilmiö on suhteessa konstruktioiden eksistentiaalisuuteen. Eksistentiaalilauseita (Creissels 2014, McNally 2016) on myös tutkittu kieltenvälisesti (Sawyer 1973, Bentley ym. 2013) ja ylipäätään monissa muissa kielissä, kuten englannissa 
(Breivik 1999, Milsark 2014), italiassa (Cruschina 2012) tai kiinassa (Hu \& Pan 2008). Koska eksistentiaalilauseita on joskus ongelmallista määritellä, niitä on myös tutkittu verbin perusteella: englanniksi voi esimerkiksi olla yhtäältä existential 'there', joka esiintyy yhdessä beverbin ('olla') kanssa, toisaalta presentational 'there', jonka yhteydessä käytetään muita verbejä (Ward 1999: 5).

Tässä artikkelissa tarkastelemme löytyä-verbin käyttäytymistä erilaisten muuttujien analyysin perusteella. Pyrimme selvittämään, miten löytyä-verbin sisältävät lauseet käyttäytyvät yhtäältä nominatiivi- ja toisaalta partitiivisubjektin yhteydessä, sekä sitä, minkälaisessa vuorovaikutuksessa tämä vaihtelu on suhteessa muihin eksistentiaalilauseeseen liitettyihin kielenpiirteisiin. Esimerkit (1) ja (2) kuvaavat vastaavasti nominatiivi- ja partitiivisubjektin käyttöä.

\section{(1) Savo löytyy Savosta! (KLK_FIN_2000) \\ (2) Taitoa löytyy kun tarvitaan. (KLK_FIN_1998)}

Tutkimuksen idea syntyi havaitessamme löytyä-verbin käyttövalikoiman laajuuden. Huomasimme, että kyseinen verbi on erittäin mielenkiintoinen semanttiselta kannalta erityisesti ns. eksistentiaalisissa konstruktioissa, mutta myös tavanomaisten nominatiivisubjektien kanssa. Toisin kuin monet muut kyseisissä konstruktioissa esiintyvät prototyyppiset "leksikaaliset eksistentiaalit" (eli muut kuin olla, ks. Larjavaara 2019: 149), kuten esimerkiksi lähteä, tulla, tippua jne., jotka yleensä kuvailevat jotakin toimintaa eivätkä pelkästään (e-)subjektin olemassaoloa, löytyä toimii monesti olla-verbin korvikkeena eli korvaa eksistentiaalisen verbin par excellence. Sen lisäksi kukaan ei ole aiemmin keskittänyt huomiota nimenomaan tähän verbiin.

Tutkimuksen pääkysymys on: mitkä muuttujat vaikuttavat löytyäverbin sisältävien lauseiden subjektien sijamuotovalintaan? Käytetty aineisto on Kansalliskirjaston lehtikokoelman (KLK) suomenkieliset lehdet 1990- ja 2000-luvulla. Valitsimme tämän aineistoksemme, sillä sen voidaan katsoa sisältävän tyypillistä nykypäivän kirjoitettua suomea ja korpus kattaa laajan valikoiman journalistisia tekstejä. Aineiston laajuus mahdollistaa sekä ilmiön tarkastelun määrällisesti tilastotieteellisiä menetelmiä käyttäen että esiinnousevien ilmiöiden tarkemman laadullisen tarkastelun. Artikkelin rakenne on seuraava: luvussa 2 esittelemme löytyä-verbillisiä lauseita aiemman tutkimuksen valossa. 
Luvussa 3 kerromme, miten olemme toteuttaneet nyt käsillä olevan tutkimuksen. Luvussa 4 siirrymme analysoimaan subjektivaihtelua sekä määrällisin että laadullisin menetelmin. Luvussa 5 teemme tutkimuksen yhteenvedon.

\section{Löytyä-verbilliset lauseet aiemman tutkimuksen valossa}

Tässä luvussa esittelemme artikkelin taustateoriaa ja terminologiaa. Alaluvussa 2.1. määrittelemme subjektin ja esittelemme eksistentiaalilauseiden kategoriaa ja sen yhteyttä subjektin sijavaihteluun. Alaluvussa 2.2. puhumme jaollisuudesta ja kvantiteetista sekä siitä, miten nämä käsitteet liittyvät lausesemantiikkaan. Lopuksi alaluvussa 2.3. kerromme lähemmin tutkimuksen lähestymistavasta sekä siitä, miksi valitsemamme muuttujat ovat tärkeitä.

\subsection{Subjektin määritelmä ja eksistentiaalilauseet}

Huumo ja Helasvuo (2015) tekevät yhteenvedon keskustelusta, jota on käyty fennistiikassa kautta aikojen: voivatko partitiivissa olevat substantiivilausekkeet oikeastaan toimia subjekteina? Heidän artikkelissaan antamaansa subjektin roolin määritelmää voidaan pitää suppeana: semanttisesta ja diskurssianalyyttisesta näkökulmasta sekä kognitiivisen kieliopin pohjalta subjekti on lauseen lähtöpiste (eng. starting point, ks. esim. Langacker 2008). Subjektia määrittelevät suomen kielessä kieliopilliset ominaisuudet kuten nominatiivimuoto, predikaatin kongruenssi sekä yleensä preverbaalinen eli temaattinen positio lauseessa (Huumo \& Helasvuo 2015: 37). Huumo ja Helasvuo suhtautuvat siis ns. partitiivisubjektiin epäilevästi ja ehdottavat erillistä 'eksistentiaalisen substantiivilausekkeen' (eng. e-NP eli existential Noun Phrase) kategoriaa. Tämän näkemyksen mukaan kaikki partitiivitunnukselliset subjektin kaltaiset substantiivilausekkeet kuuluvat siis eksistentiaalilauseeseen. Tätä näkökulmaa edustaa esimerkiksi Ikola (1954: 224-226), jonka mukaan partitiivisubjektit esiintyvät ainoastaan eksistentiaalilauseissa, jotka sallivat myös nominatiivisubjekteja. Toinen semanttista roolia luonnehtiva ja kaikki eksistentiaaliset subjektit kattava käsite on Huumon (2003: 462) e-theme.

Vakiintuneet eksistentiaalilauseet ovat sanajärjestykseltään konstruktioita, joissa adverbiaali sijoittuu yleensä temaattiseen, verbiä 
edeltävään positioon. Sanajärjestys voi kuitenkin olla käänteinen, missä tapauksessa e-subjekti esiintyy ennen verbiä ja paikkaa ilmaiseva adverbiaali sen jälkeen, eikä kongruenssia ole. Jos lause sen sijaan kongruoi eli subjekti on esimerkiksi monikon nominatiivissa ja verbi monikon 3. persoonassa, kyseessä on sijaintia ilmaiseva normaalilause (vrt. Hakanen 1972, Larjavaara 2019: 118; sijainnin ilmaisemisesta [engl. locational predication], ks. myös Creissels 2014): lause ei siis tuo esiin uutta referenttiä eikä näkökulma ole eksistentiaalilauseista poiketen holistinen (ks. myös Lees 2015: 7). Ivaska (2011: 81) osoittaa, että oppijankielen kontekstissa lauseissa käytetyt epäprototyyppiset piirteet johtavat usein lausetyyppien sekoittumiseen: toisin sanoen eksistentiaalisen ja ei-eksistentiaalisen lauseen välinen raja hämärtyy (termeistä eksistentiaalilause ja eksistentiaalinen lause ks. Ivaska 2010, 2011) eikä välttämättä ole mahdollista erottaa eksistentiaalilauseita muista lausetyypeistä kategorisesti ainoastaan subjektin sijamuodon, kongruenssin tai sanajärjestyksen perusteella. Alaluvussa 2.3. käsittelemme yksityiskohtaisemmin tällaisten muuttujien vaikutusta lausetyyppien määrittelemiseen.

\subsection{Subjektin semantiikan vaikutus lausesemantiikkaan}

Löytyä-verbillisten lauseiden semanttiset piirteet kiertyvät osaksi keskustelua lauseiden eksistentiaalisuudesta, ja esimerkiksi subjektin jaollisuus vaikuttaa lauseiden semanttiseen tulkintaan. ISK:ssa käytetään termejä jaollinen ja jaoton (VISK §554-555) viitaten subjektin tarkoitteeseen. Larjavaara (1988) käyttää termiä avoin (vrt. sulkeinen) kuvatessaan jaolliseen subjektin tarkoitteeseen viittaavia ns. ainesanoja tai jaottomia kappalesanoja monikon partitiivissa (ks. myös Huumo 2003); sulkeisia ovat toisaalta kaikki jaottomiin subjektin tarkoitteisiin viittaavat kappalesanat. Sijanvalinta vaikuttaa kuitenkin monesti jaollisten ainesanojen kvantiteettiin: lauseessa Viini on lasissa subjektin kvantiteettia käsitellään siis sulkeisena (vrt. avoimeen vaihtoehtoon Viiniä on lasissa). Jos prototyyppisesti jaoton subjekti on monikkomuotoisena partitiivissa, muuttaa sijamerkintä subjektin kvantiteetin avoimeksi. Tämä vaikuttaa myös verbin lukuun, sillä tällaisessa tapauksessa verbi ei sulkeisesta kvantiteetista poiketen kongruoi subjektin kanssa. Monikollisia verbitapauksia on tästä syystä eksistentiaalilauseiden joukossa huomattavasti vähemmän kuin yksiköllisiä. 
Partitiivisubjekti ja inkongruenssi ovat siis tärkeitä elementtejä eksistentiaalilauseen määrittämisessä esimerkiksi Hakasen (1972) mukaan. Prototyyppisellä eksistentiaalilauseella on myös tietty rakenne, jolla luonnehditaan alussa olevan lokatiiviadverbiaalin tarkoitetta kertomalla mitä tämä sisältää sekä esitetään diskurssiin uusia epämääräisiä substantiivilausekkeita, jotka voivat olla nominatiivi- tai partitiivisijaisia (Huumo \& Lindström 2014: 154). Tässä rakenteessa yllä mainitut substantiivilausekkeet eivät kuitenkaan ole prototyyppisiä subjekteja vaan e-subjekteja, joilla on eksistentiaalinen funktio yhtä hyvin myös lauseen alussa, mikäli ne ovat partitiivissa.

\subsection{Tutkimuksen lähestymistapa sekä muuttujien esittely}

Lähestymme löytyä-verbillisiä lauseita käyttöpohjaisesta näkökulmasta konstruktiokieliopin avulla (Goldberg 1995, 2006): lähdemme liikkeelle siitä oletuksesta, että nominatiivi-partitiivi -vaihteluun vaikuttaa samanaikaisesti useita toisiinsa kietoutuneita muuttujia, jotka kaikki osaltaan vaikuttavat sijamerkintään. Näiden eri muuttujien välinen vuorovaikutteinen kokonaisuus ohjaa konstruktion kokonaismerkityksen hahmottumista joko eksistentiaaliseksi tai sijaintia ilmaisevaksi normaalilauseeksi. Seuraavaksi esittelemme tarkastelemamme muuttujat. Kaikki muuttujat on valikoitu aiemman tutkimuksen perusteella: riippumattoman eli selitettävän muuttujamme eli subjektin sijamuodon lisäksi myös riippuvat eli selittävät muuttujamme kuten kongruenssi, sanajärjestys, sekä subjektin luku ja jaollisuus ovat lauseen eksistentiaalisuuteen tyypillisesti yhdistettyjä kielenpiirteitä. Aikamuoto on syytä ottaa huomioon, jotta voidaan huomioida sen mahdollinen suhde lauseen aspektiin ja teonlaatuun. Verbin aikamuodon suhde muihin lauseen kieliopillisiin ominaisuuksiin (kuten tässä tutkimuksessa e-NP:n sijamuoto) määrittää lauseen aspektia, kun taas lauseen teonlaatu on sidottu verbilekseemien aspektiominaisuuksiin (VISK $§ 1500$ ). Subjektin sanaluokka - ennen kaikkea pronominien ja substantiivien välinen suhde puolestaan liittyy siihen Helasvuon (1996: 352) esittämään huomioon, että "[eksistentiaalilauseiden subjektit] eivät ole diskurssin kannalta keskeisiä vaan jäävät useimmiten kertamaininnan varaan." Pronominien tarkoitteet määrittyvät tyypillisesti kontekstissaan joko deiktisesti tai anaforisesti (VISK §714), mistä syystä ne eivät lähtökohtaisesti vastaa Helasvuon määritelmää tyypillisestä eksistentiaalilauseen subjektista. 
Subjektin lemman sisällyttäminen tarkastelunalaisiin muuttujiin sen sijaan mahdollistaa kollostruktionaalisten preferenssien eli konstruktion ja siinä esiintyvien sanojen myötäesiintymä-suhteiden huomioimisen (Stefanowitsch \& Gries 2003, Gries \& Stefanowitsch 2004).

Aiemman tutkimuksen perusteella tärkeimmät muuttujat subjektin sijamuotovaihtelun määrittämisessä ovat subjektin luku (3) suhteessa verbin lukuun (muuttujana kongruenssi kyllä $3 a$ ja 3b/ei 3c) sekä subjektin jaollisuuteen (jaollinen 3a/jaoton $3 b$ ) ja sanajärjestykseen (SV 3c, VS 3d). Näiden kaikkien muuttujien lisäksi käytetään subjektin sanaluokkaa eli substantiivia (NP, 3a) tai muita (3e), niin kuin adjektiiveja, pronomineja, partisiippeja $(-v A$ tai $-n U t)$ ja 4. infinitiivejä sekä aikamuotoja (preesens 3a, preteriti 3c, perfekti 3f). Satunnaismuuttujana eli muuttujana, jonka kaikkia mahdollisia arvoja ei ole ennalta määritelty, on subjektin lemma.

(3) a. Luomu löytyy yhdeltä kartalta. (KLK_FI_1999)

b. Tyypilliset esimerkit löytyvät pääkaupunkiseudulta. (KLK_FI_1999)

c. Kumiteriäkin löytyi - tosin vain hirvittäviä kokoja. (KLK_FI_1998)

d. Näyttelemistyyleistä löytyi myös eroja. (KLK_FI_1997)

e. Silti pelattavaa löytyy. (KLK_FI_1996)

f. Jonkunlainen malli on löytynytkin. (KLK_FI_1996)

Larjavaara (2019: 12) esimerkiksi selittää, että "partitiivin lauseopillinen eli syntaktinen luonne määräytyy lähes kokonaan sen eri merkityksistä (= semantiikasta). Sijan merkitys ja syntaksi sulautuvat yhteen". Konstruktiokieliopin perusperiaate selittää satunnaismuuttujamme (eli subjektin lemman) vaikutuksen lauseiden merkityksiin. Toisin sanoen, koska konstruktiomerkitykset kumpuavat prototyyppisistä käytöstä ja prototyyppisessä käytössä useimmin esiintyvien sanojen merkityksestä (Goldberg, Casenheiser \& Sethuraman 2004), eri käyttökontekstien sanojen voidaan olettaa preferoivan eri konstruktioita.

\section{Tutkimuksen toteutus}

Tämä luku koostuu kahdesta alaluvusta, joissa kerromme, miten toteutamme tutkimuksen. Aloitamme esittelemällä käyttämämme aineiston, minkä jälkeen kuvaamme ne menetelmät, joilla analysoimme aineistoa. 


\subsection{Aineisto}

Aineistona käytetään Kansalliskirjaston lehtikokoelman (KLK) suomenkielisiä lehtiä. Tarkastelumme on luonteeltaan synkronista, mistä syystä olemme rajanneet tarkastelumme vuoden 1990 alun ja vuoden 2000 lopun väliseen aineistoon. Tutkimuksen toteutettavuuden vuoksi emme ole analysoineet korpuksen kaikkia 48969 löytyä-verbin sisältävää lausekontekstia yksityiskohtaisesti, vaan olemme nostaneet tarkastelun kohteeksi 500 affirmatiivisesta SV-lauseesta ja 500 affirmatiivisesta VS-lauseesta koostuvan tasapainotetun satunnaisotoksen. Ratkaisu on konstruktioiden sisäistä ja lähikonstruktioiden välistä vaihtelua tarkastelevassa tutkimuksessa tyypillinen (ks. esim. Gries \& Wulff 2013, Klavan 2020), sillä näin voidaan varmistaa, että tilastollisessa analyysissa voidaan mallintaa tarkasteltavan ilmiön (tässä: subjektin sijamerkintä) vaihtelua tasapainoisesti (ks. tarkemmin 3.2). Kieltolauseet on jätetty tarkastelun ulkopuolelle, sillä niissä eksistentiaalilauseen subjekti esiintyy odotuksenmukaisesti partiivimuotoisena riippumatta muista sijamerkintään vaikuttavista tekijöistä. Lopullinen aineisto koostuu 779 lauseesta, joista SV-lauseita on 387 ja VS-lauseita 392. Tämä eroavuus johtuu ensinnäkin siitä, että molemmissa ryhmissä (SV ja VS) esiintyi vastakkaisen ryhmän esimerkkilauseita johtuen korpuksen lukuvirheistä mutta myös siitä, että Taulukossa 1 olevat lauseet poistettiin.

Taulukko 1. Poistetut lauseet.

\begin{tabular}{l|r}
\hline Kieltolauseet & 39 \\
\hline Kvanttori- ja numeraalilauseet & 95 \\
\hline Löytyä ei pääverbinä & 49 \\
\hline Tapaluokka potentiaali & 6 \\
\hline Aikamuoto pluskvamperfekti & 2 \\
\hline Muut ongelmalliset & 29 \\
\hline Löytyä-verbin käyttö 2. persoonassa & 1 \\
\hline Yhteensä & 221 \\
\hline
\end{tabular}

39 kieltolausetta jätettiin tarkastelun ulkopuolelle, sillä ne olivat virheellisesti jääneet tunnistamatta negatiivisiksi. VISK:n mukaan (§ 902) intransitiiviset kvanttorilauseet esiintyvät myös löytyä-verbin yhteydessä 
ja niillä on eksistentiaalilauseen piirteitä. Jätimme kvanttorilauseet pois tarkastelusta, sillä niissä ei yleensä ole subjektin sijavaihtelua vaan (e-)subjektit esiintyvät partitiivissa. Intransitiivisen kvanttorilauseen tuntomerkkejä näkyy erityisesti SV-lauseissa (4), joissa partitiivimuotoista subjektia (e-subjektia) seuraavat predikaatti ja määränilmaus:

(4) [...] ruumiita oli torstaiaamuun mennessä löytynyt 41. (KLK_FI_1994)

VS-vastineiden (5) teemana on yleensä elatiivi- tai ablatiivimuotoinen adverbiaali myös kvanttorilausekkeiden kanssa:

(5) Aasiasta löytyy paljon esimerkkejä. (KLK_FI_1999)

Monessa esimerkkilauseessa löytyä-verbi esiintyy 1 . infinitiivinä (6) modaaliverbin kanssa tai 1. partisiippina (7), monesti verbien saattaa (8), arvella, näyttää tai uskoa kanssa:

(6) Muutamille voi löytyä virka myös yläasteelta. (KLK_FI_2000)

(7) Paras oivallus valmistajalta ovat kuitenkin vakiona autosta löytyvät kuormakiskot. (KLK_FI_1999)

(8) Myöhemmin rakennuksesta saattaa kuitenkin löytyä merkittävä homeongelma. (KLK_FI_1999)

Yllä mainituissa lauseissa löytyä ei ole pääverbinä. Kategoriaan "Muut ongelmalliset" kuuluvat kaikki ne lauseet, jotka eivät syystä tai toisesta ole ymmärrettäviä: monesta puuttuu olennainen osa tai sanat ovat automaattisen tekstien digitoimisprosessin virheiden vuoksi fragmentoituneita. Tuhannesta esimerkkilauseesta vain yhdessä esiintyy löytyä-verbin käyttö 2. persoonassa (9).

(9) Mistä löydyt prinssini, 44-50-v. fiksu, pitkähkö, ulkonäkö ok, pilke silmäkulmassa, lenkkeilet ja tanssit. (KLK_FI_1997)

Ongelmallisia tapauksia oli myös sen tyyppisissä lauseissa (10), joissa koko lauseen näkökulmasta tarkoitteeltaan monikolliseksi käsitettävä, subjektina toimiva substantiivilauseke koostuu kahdesta yksikön nominatiivimuodossa olevasta substantiivista. Analyysin perusteella 
tiedämme kuitenkin, että verbin monikkomuotoisuus edellyttää aina tarkoitteeltaan monikolliseksi käsitettävää subjektia.

(10) Äiti ja lapsi löytyivät surmattuina torstaina iltapäivällä Nivalassa. (KLK_ FI_1995)

Lopullisessa aineistossa nominatiiviesiintymiä on 455 kappaletta ja partitiiviesiintymiä 324 kappaletta.

\subsection{Menetelmät}

Tarkastelemme löytyä-verbillisten lauseiden subjektien sijanvalintaa sekä määrällisin että laadullisin menetelmin. Määrällisessä osassa tarkastelemme monimuuttujaisen logistisen sekamallin (ks. esim. Gries 2015) avulla sitä, mitkä edellä käsitellyt, aiemman tutkimuskirjallisuuden perusteella identifioidut lauseen eksistentiaalisuuden tulkintaa ohjaavat muuttujat vaikuttavat sijanvalintaan joko yksin tai vuorovaikutuksessa keskenään. Tavoitteena on siis kuvata ja mallintaa löytyäverbillisten lauseiden subjektien sijavaihteluun vaikuttavia osatekijöitä, ei sitä, mikä on löytyä-verbille ylipäätään tyypillistä ja mikä ei. Kaikki muuttujat esitellään Taulukossa 2 (tämän alaluvun lopussa).

Logistinen sekamalli tarkoittaa regressioanalyysia, jossa kaksiarvoista riippuvaa muuttujaa - tässä tutkimuksessa subjektin sijanvalintaa - ennustetaan sekä kiinteillä muuttujilla että satunnaismuuttujilla. Kiinteiden muuttujien mahdolliset arvot tulevat ennalta tiedetystä joukosta (esim. subjektin ja verbin välinen sanajärjestys) kun taas satunnaismuuttujien arvot valikoituvat suuremmasta, ennalta määrittämättömästä joukosta mahdollisia arvoja. Tämän tutkimuksen muuttujista subjektin lemma on ainoa satunnaismuuttuja, sillä muiden muuttujien kaikki mahdolliset arvot on määritelty etukäteen. Regressioanalyysissa on kaksi selvää etua perinteiseen, yksittäisiä muuttujia ja niiden merkitystä kutakin erikseen tarkastelevaan lähestymiseen. Yhtäältä se vakioi muuttujat suhteessa toisiinsa niin, että kunkin muuttujan vaikutusta ja merkitystä voidaan tarkastella suhteessa muihin muuttujiin: miten muuttuja X vaikuttaa tarkastelunalaiseen ilmiöön, kun kaikki muut muuttujat pysyvät samoina. Toisaalta se mahdollistaa myös muuttujien välisen vuorovaikutuksen tarkastelun: vaikuttaako muuttuja $\mathrm{X}$ tarkastelunalaiseen ilmiöön eri tavoin silloin, kun muuttujan Y arvo muuttuu? On syytä korostaa, 
että monien tarkastelunalaisten muuttujien - kuten subjektin jaollisuuden ja luvun suhde - vaikutus sijavaihteluun on kuvattu aiemmassa tutkimuksessa huolellisesti ja tunnetaan hyvin. Näiden huomioiminen osana tilastollista analyysia on kuitenkin ensiarvoisen tärkeää, jotta eri muuttujien ja niiden välisen vuorovaikutuksen vaikutus sijamerkintään voidaan mallintaa luotettavasti. Tähän perustuu myös aineiston edellä (ks. 3.1) kuvattu, VS- ja SV-sanajärjestyksellisiä löytyä-lauseita tasapainoisesti sisältävä satunnaisotos. Satunnaisotos kaikista löytyäverbillisistä lauseista kuvaisi näiden lauseiden käyttöä ylipäätään, mutta se ei kuitenkaan mahdollistaisi harvinaisempien käyttökontekstien vaikutusten luotettavaa mallintamista.

Tutkimusasetelmamme on luonteeltaan konfirmatorinen eikä eksploratorinen, ja kaikki malliin sisällytetyt muuttujat samoin kuin niiden mahdolliset keskinäiset vuorovaikutussuhteet ovat aiemman tutkimuksen motivoimia, mistä syystä emme pyri optimoimaan mallia muuttujanvalintamenetelmien avulla (ks. Winter 2020: 277-279). Emme myöskään tarkastele mallin tilastollista merkitsevyyttä kokonaisuudessaan vaan kuvaamme sen ennustavuutta niin sanotun R-neliön avulla. R-neliö kuvaa sitä, kuinka hyvin riippuvan muuttujan vaihtelu tässä tutkimuksessa subjektin sijamerkintä - voidaan ennustaa riippumattomien muuttujien avulla. R-neliön arvot vaihtelevat $0: n$ ja 1:n välillä niin, että 1 indikoi mallin riippumattomien muuttujien ennustavan vaihtelun täydellisesti ja 0 ei lainkaan. Tarkastelemme kuitenkin kunkin muuttujan tilastollista merkitsevyyttä vertaamalla ANOVA-testin avulla käyttämäämme mallia sellaiseen, josta kulloinkin kyseessä oleva muuttuja on jätetty pois (ks. Winter 2020: 260-263). Vakiintuneen käytännön mukaisesti tilastollisen merkitsevyyden kynnysarvo on $p=0.05$. Kaikki tilastolliset analyysit on tehty R-ohjelmointiympäristössä (R Core Team 2018), ja sekamalleissa olemme käyttäneet lme4-pakettia (Bates ym. 2015), R-neliön laskemiseen MuMI n-pakettia (Bartoń 2018) ja mallia havainnollistavien kuvaajien tekoon effects-pakettia (Fox \& Hong 2009).

Lopullinen mallimme on seuraava:

\author{
SUBCASE $\sim$ SUBQUAN + \\ SUBNUM + \\ SUBQUAN:SUBNUM + \\ AGREEMENT +
}




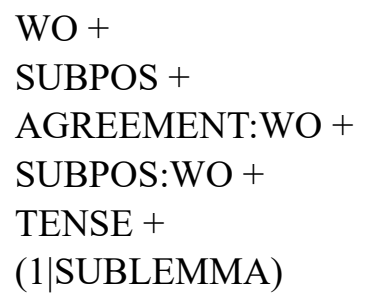

Edellä kuvattujen muuttujien yksittäistarkastelun lisäksi tarkastelemme siis myös subjektin jaollisuuden ja subjektin luvun välistä vuorovaikutusta, verbin ja subjektin välisen kongruenssin ja subjektin ja verbin välisen sanajärjestyksen välistä vuorovaikutusta sekä subjektin sanaluokan ja subjektin ja verbin välisen sanajärjestyksen välistä vuorovaikutusta. Nämä vuorovaikutukset ovat kieliopillisesti perusteltuja: subjektin semanttinen jaollisuus on sidoksissa lukuun niin, että prototyyppisesti jaolliset eivät tyypillisesti esiinny monikkomuotoisina (VISK §555). Vastaavasti niin kongruenssi kuin sanajärjestyskin kuvaavat nimenomaan verbin ja subjektin luvun välistä suhdetta, minkä lisäksi niin kongruoimattomuutta kuin VS-sanajärjestystäkin on tyypillisesti pidetty partitiivisijaisen subjektin kanssa eksistentiaalilauseen ominaispiirteinä (Hakanen 1972). Myös subjektin sanaluokan osalta etenkin pronominien voidaan olettaa deiktisen tulkintansa vuoksi vaikuttavan lauseiden informaatiorakenteeseen ja sen myötä sanajärjestykseen. Lisäksi nämä ilmiöt saattavat tahoillaan vaikuttaa lausetyyppien sekoittumiseen vuorovaikutuksessa sanajärjestyksen kanssa (Ivaska 2011), mistä syystä niiden väliset mahdolliset vaikutussuhteet on syytä ottaa huomioon myös tilastollisessa analyysissa.

Tämän jälkeen keskitymme kuvaamaan laadullisesti näitä havaittuja ilmiöitä suhteessa aiempaan tutkimukseen. Pyrimme tällä tavoin vastaamaan tutkimuskysymykseen mahdollisimman kattavasti menetelmällisen triangulaation keinoin, käyttämällä peräkkäistä monimenetelmäisyyttä (engl. sequential mixed methods), jossa määrällisen analyysin tulokset ohjaavat laadullista analyysia (määrällisten ja laadullisten menetelmien yhdistämisestä ks. esim. Hashemi 2012). 
Taulukko 2. Tilastollisessa analyysissa käytetyt muuttujat ja niiden esiintymämäärät aineistossa.

\begin{tabular}{|c|c|c|}
\hline MUUTTUJA & ARVOT & LÄHDE \\
\hline $\begin{array}{l}\text { SUBCASE: } \\
\text { subjektin sija }\end{array}$ & $\begin{array}{l}\text { nom (nominatiivi): } 455 \\
\text { part (partitiivi): } 324\end{array}$ & $\begin{array}{l}\text { Korpuksen annotaatio } \\
\text { (tarkastettu) }\end{array}$ \\
\hline $\begin{array}{l}\text { SUBQUAN: } \\
\text { subjektin jaollisuus }\end{array}$ & $\begin{array}{l}\text { count (jaoton): } 603 \\
\text { uncount (jaollinen): } 176\end{array}$ & $\begin{array}{l}\text { Manuaalinen } \\
\text { annotaatio }\end{array}$ \\
\hline $\begin{array}{l}\text { SUBNUM: } \\
\text { subjektin luku }\end{array}$ & $\begin{array}{l}\text { sg (yksikkö): } 495 \\
\text { pl (monikko): } 284\end{array}$ & $\begin{array}{l}\text { Korpuksen annotaatio } \\
\text { (tarkastettu) }\end{array}$ \\
\hline $\begin{array}{l}\text { VERBNUMBER: } \\
\text { verbin luku }\end{array}$ & $\begin{array}{l}\text { sg (yksikkö): } 687 \\
\text { pl (monikko): } 92\end{array}$ & $\begin{array}{l}\text { Korpuksen annotaatio } \\
\text { (tarkastettu) }\end{array}$ \\
\hline $\begin{array}{l}\text { AGREEMENT: } \\
\text { kongruenssi }\end{array}$ & $\begin{array}{l}\text { yes (subjekti ja verbi } \\
\text { samassa luvussa): } 575 \\
\text { no (subjekti ja verbi eri } \\
\text { luvussa): } 204\end{array}$ & $\begin{array}{l}\text { Korpuksen annotaatio } \\
\text { (tarkastettu) }\end{array}$ \\
\hline $\begin{array}{l}\text { SUBPOS: } \\
\text { subjektin } \\
\text { sanaluokka }\end{array}$ & $\begin{array}{l}\text { N (substantiivi): } 724 \\
\text { A (adjektiivi): } 15 \\
\text { Pron (pronomini): } 30 \\
\text { V (verbi): } 10\end{array}$ & $\begin{array}{l}\text { Korpuksen annotaatio } \\
\text { (tarkastettu) }\end{array}$ \\
\hline $\begin{array}{l}\text { WO: } \\
\text { sanajärjestys }\end{array}$ & $\begin{array}{l}\text { SV (subjekti ennen } \\
\text { verbiä): } 387 \\
\text { VS (verbi ennen } \\
\text { subjektia): } 392\end{array}$ & $\begin{array}{l}\text { Korpuksen annotaatio } \\
\text { (tarkastettu) }\end{array}$ \\
\hline $\begin{array}{l}\text { TENSE: } \\
\text { aikamuoto }\end{array}$ & $\begin{array}{l}\text { PRES (preesens): } 554 \\
\text { IMPERF (preteriti): } 187 \\
\text { PERF (perfekti): } 38\end{array}$ & $\begin{array}{l}\text { Korpuksen annotaatio } \\
\text { (tarkastettu) }\end{array}$ \\
\hline $\begin{array}{l}\text { SUBLEMMA: } \\
\text { subjektin lemma }\end{array}$ & $\begin{array}{l}\text { satunnaismuuttuja, jolla } \\
\text { aineistossa } 568 \text { eri arvoa }\end{array}$ & $\begin{array}{l}\text { Korpuksen annotaatio } \\
\text { (tarkastettu) }\end{array}$ \\
\hline
\end{tabular}

\section{Analyysi}

Tilastollinen mallimme onnistuu kuvaamaan subjektin sijavalinnassa esiintyvän vaihtelun melko hyvin $\left(\mathrm{R}^{2}\right.$ marginaalinen $=0.65, \mathrm{R}^{2}$ ehdollinen $\left.=0.73\right)$. Marginaalinen R-neliö kuvaa mallin kiinteiden muuttujien ennustavuutta ja ehdollinen R-neliö kiinteiden ja satunnaismuuttujan yhteistä ennustavuutta. Muuttujien keskinäisen riippuvuuden mittari (engl. 
Variance Inflation Factor) ei myöskään indikoi muuttujien liiallista multikollineaarisuutta, sillä kaikki arvot ovat selvästi alle yleisenä kynnysarvona pidetyn 10:n. Näin ollen voimmekin oikeutetusti siirtyä tarkastelemaan tuloksia kunkin muuttujan osalta.

\subsection{Subjektin jaollisuus ja luku}

Täyden mallin vertaaminen malliin, jossa subjektin jaollisuudella ja luvulla ei ole vuorovaikutussuhdetta, osoittaa, että vuorovaikutus on tilastollisesti erittäin merkitsevä (LRT X(1)=17.056, $p<0.0001$ ). Edelleen, kun tätä mallia verrataan malleihin joista nämä muuttujat on vuorollaan jätetty pois, nähdään, että jaollisuudella (LRT X(1)=282.14, $p<0.0001)$ on myös itsessään tilastollisesti erittäin merkitsevä vaikutus subjektin sijanvalintaan, kun taas luvulla ei ole (LRT X(1) $=0.1624$, $p=0.6869$ ).

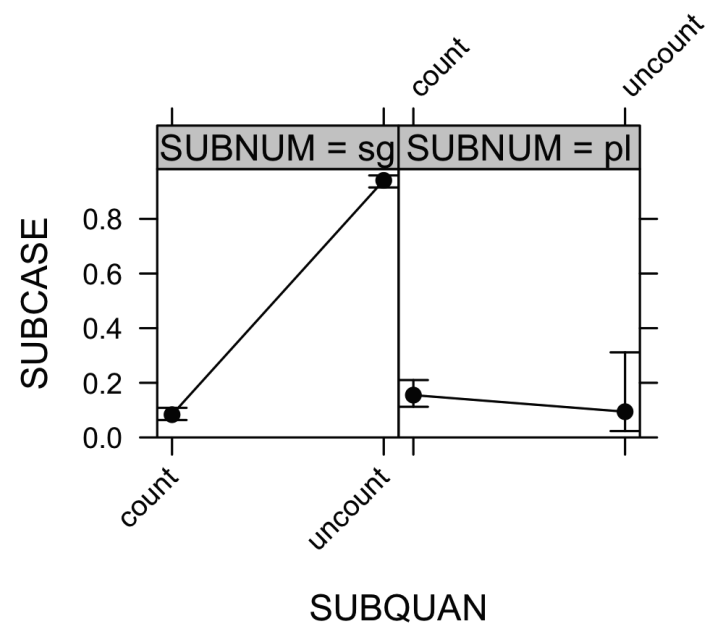

Kuvio 1. Subjektin jaollisuuden ja luvun suhde subjektin sijamerkintään ${ }^{1}$.

1 Kuviot 1-4 kuvaavat tarkasteltujen muuttujien vaikutusta löytyä-verbillisten lauseiden subjektin sijanvalintaan. Pystyakselin arvot vaihtelevat välillä 0-1 niin, että pienemmät arvot tarkoittavat todennäköistä nominatiivisubjektia ja suuremmat arvot todennäköistä partitiivisubjektia. Kuvion 1 vasemmanpuoleisesta paneelista näkyy, että yksikkömuotoisten subjektien (SUBNUM $=\mathrm{sg}$ ) kohdalla subjektin jaollisuus (uncount) lisää partitiivisijaisuuden todennäköisyyttä kun taas monikkomuotoisten subjektien $(\mathrm{SUBNUM}=\mathrm{pl})$ kohdalla näin ei ole. 
Kuten Kuvio 1 havainnollistaa, prototyyppisesti jaottomat (tai laskettavat, 'count') subjektit ovat yksikössä lähes poikkeuksetta nominatiivimuotoisia (y-akselin arvo on lähellä $0: a a)$, ja subjektin prototyyppinen jaollisuus (ei-laskettavuus, 'uncount') lisää partitiivin todennäköisyyttä. Subjektin monikollisuus lisää partitiivin todennäköisyyttä prototyyppisesti jaottomien osalta (esim. sanat-sanoja), ja tällaisia monikkomuotoja onkin perinteisesti pidetty jaollisina. Kun monikollinen jaoton subjekti on partitiivissa, tilanne voidaan tulkita joko kollektiivisena tai distributiivisena (Huumo 2006, Vilkuna 1992). Lause (11) voi mahdollisesti olla kumpaakin: kollektiivinen, sillä parkkipaikat ovat kaikki samanaikaisesti olemassa; distributiivinen, sillä niitä vapautuu ja täyttyy jatkuvasti, eikä koskaan ole sama parkkipaikka vapaana verrattuna esimerkiksi aikaisempaan tuntiin. Kollektiivisessa tulkinnassa viitataan pääasiassa parkkipaikkojen olemassaoloon eikä siihen, että ne ovat vapaina toiminnan hetkellä. Lause (12) luetaan taas pääosin distributiivisena, sillä lauseen lopussa oleva adverbiaali antaa ymmärtää, että osallistujia on monenlaisiin erilaisiin kohteisiin sekä mahdollisesti peräkkäisinä hetkinä.

(11) Mutta myös parkkipaikkoja löytyy konserttipaikan vierestä. (KLK_ FI_1997)

(12) Dharman kampanja alkaa hyvin, avustajia löytyy kaikkiin tehtäviin. (KLK_FI_1999)

Jaollisten subjektien kohdalla (esim. rahat-rahoja) subjektin monikollisuus ei lisää partitiivin todennäköisyyttä. Tällaisia tapauksia on aineistossa ainoastaan kymmenen, ja nähdäksemme nämä tapaukset ovat esimerkkejä tilanteista, joissa prototyyppisesti jaollisten tarkoitteiden jaottomuutta ilmaistaan nimenomaan lukumerkinnän avulla - niin, että ne kuvaavat esimerkiksi laskettavien alkioiden joukkoa (13).

(13) Poliisi on vihdoin päässyt murtomiehen jäljille, ja Ukon rahatkin löytyvät. (KLK_FI_1995)

Sanan raha kaltaiset tapaukset voidaan ymmärtää myös puhtaan jaottomaksi (esim. kolikko), mutta olemme päättäneet käsitellä aineiston raha-tyyppisiä sanoja jaollisina, jotta soveltamamme tilastollinen menetelmä heijastaisi tätä edellä kuvattua vaihtelua: nähdäksemme 
kyseessä on prototyyppisesti jaollisten tarkoitteiden joukko, jonka semanttista tulkintaa ohjataan numeruksen avulla tunnusmerkkiseen jaottomaan (laskettavaan) suuntaan - ja näin sijamerkintä, jaollisuus ja luku muodostavat vuorovaikutteisen kokonaisuuden. Sama koskee myös sanoja työ (14), ruoka (15) tai vesi (16).

(14) Hänen tavoitteenaan on olla Kaliforniassa ainakin puoli vuotta ja jos töitä löytyy, pitempäänkin. (KLK_FI_1993)

(15) Sadan erilaisen ohjeen joukosta löytyy kylmiä ruokia, salaatteja, keittoja, patoja ja risottoja, kastikkeita, laatikoita, paistoksia, murekeruokia, fileitä ja annospaloja. (KLK_FI_1999)

(16) Mistä löytyy sulimmat uimavedet? (KLK_FI_1996)

Vastaavasti prototyyppisesti laskettava, jaoton yksiköllinen subjekti kuvaa monikossa jaollista paljoutta, joka voi olla indefiniittinen ja ilmaista partitiivissa avokvantiteettia (17) tai definiittinen ja ilmaista nominatiivissa sulkeiskvantiteettia (18). Katsoimme silti tarpeelliseksi säilyttää määrällisen analyysin muuttujien koodauksessa eri paljouksien yksittäisten tarkoitteiden prototyyppisen jaottomuuden (count), jotta näkisimme, millaisessa vuorovaikutuksessa se on subjektin luvun kanssa. Monikollinen nominatiiviviittaus voi joka tapauksessa kohdistua myös jaottomaan kohteeseen (ks. Larjavaara 2019: 184) tai määrittää jaotontarkoitteista paria, settiä tai nippua (ks. myös 4.2, jossa näiden roolia analysoidaan sanajärjestyksen kannalta): käsittääksemme paljous- ja settitulkinnan välinen raja ei kuitenkaan ole aina aivan selvä.

(17) Muita kuvauspaikkoja on löytynyt muun muassa Suomenlinnasta (...). (KLK_FI_1999)

(18) Puhelinnumerot löytyvät jäsenkirjeestä. (KLK_FI_1996)

Tarkasteltaessa laadullisesti niitä tapauksia, joissa prototyyppisesti jaoton subjekti esiintyy yksikössä partitiivimuotoisena, huomio kiinnittyy lauseiden interrogatiivisuuteen ja siihen liittyvään tarkoitteiden avoimuuteen: esimerkin (19) hienoa herraa ja esimerkin (20) somaa, muodokasta naista ovat kumpikin tarkoitteiltaan sekä epäspesifejä että indefiniittisiä, mitä tulkintaa partitiivisijaisuus ilmaisee. 
(19) Löytyisikö varakasta, hienoa herraa, joka olisi tarpeessa edustuskelpoisesta, sivistyneestä naisesta, ehkä kutsuilla, matkoilla, työasioista, apukättä. (KLK_FI_1999)

(20) Löytyykö rehell., omlll. toim. tulevaa, 50-57-v., somaa, muodokasta naista, et tupakoi etkä liioin kapakoi. (KLK_FI_1999)

Tulokset ovat monin osin odotuksenmukaiset ja seuraavat aiempaa tutkimusta, sillä jaollisuus ja luku ovat luonnollisesti toisiinsa kietoutuneita syntaktis-semanttisia ilmiöitä. On kuitenkin huomionarvoista, että subjektin prototyyppinen jaollisuus lisää partitiivisubjektin todennäköisyyttä vain yksiköllisenä. Tämän voidaan katsoa tarkoittavan sitä, että monikollisuus muuttaa automaattisesti subjektin semanttista kategoriaa. Vastaavasti yksikkömuotoisten prototyyppisesti jaottomien subjektien partitiivisijaisuus näyttäytyy keinona, jolla ohjataan tarkoitteiden semanttista tulkintaa epäspesifiksi ja indefiniittiseksi.

\subsection{Kongruenssi ja sanajärjestys}

Kongruenssin ja sanajärjestyksen välinen vuorovaikutus on tilastollisesti merkitsevä $(\operatorname{LRT~X}(1)=6.9673, p=0.008301)$. Tämän mallin vertaaminen edelleen malliin ilman kongruenssia osoittaa lisäksi, että kongruenssin vaikutus subjektin sijanvalintaan on tilastollisesti erittäin merkitsevä myös itsessään (LRT X(1)=195.61, $p<0.0001)$. Myös sanajärjestys itsessään vaikuttaa tilastollisesti merkitsevästi subjektin sijanvalintaan $(\operatorname{LRT} X(5)=11.671, p=0.03959)$, mutta tulos ei ole täysin verrannollinen, sillä sanajärjestyksen poistaminen mallista vaikuttaa myös sen vuorovaikutukseen subjektin sanaluokan kanssa (ks. 4.3). Kuten Kuviosta 2 nähdään, partitiivisubjektit ovat huomattavasti todennäköisempiä silloin, kun subjekti ja verbi eivät kongruoi (y-akselin arvo on lähellä 1:ä, mikä tarkoittaa, että se on useimmiten partitiivissa). Kuten odottaa saattaa, myös VS-sanajärjestys lisää partitiivisubjektin todennäköisyyttä edelleen. Nämä molemmat seikat osoittavat sen, miten molemmat muuttujat osaltaan ohjaavat kohti eksistentiaalista tulkintaa. Tämä heijastanee lauseen eksistentiaalisuuden ilmaisemiseen liittyvää rajankäyntiä: kun yksi tyyppipiirteistä - kuten inkongruenssi eli subjektin ja verbin erilukuisuus - täyttyy, muilla tyyppipiirteillä - kuten sanajärjestyksellä - on vähemmän merkitystä. 


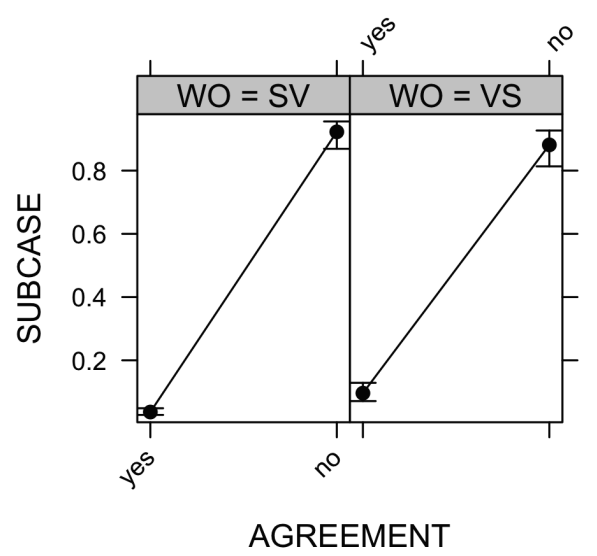

Kuvio 2. Kongruenssin ja sanajärjestyksen suhde subjektin sijamerkintään.

Verbin kanssa kongruoimaton monikollinen nominatiivisubjekti esiintyy yhteensä 20 esimerkkilauseessa: kyse on nähdäksemme ns. pareista (21), seteistä (22) tai nipuista (ks. Larjavaara 2019: 184), minkä takia inkongruenssi on mahdollinen, mutta VS-järjestyksellisissä lauseissa luontevampi kuin SV-järjestyksellisissä.

(21) Tanssikengät löytyy. (KLK_FI_1998)

(22) Tuotteet löytyy myös rannasta. (KLK_FI_1995)

Kongruoimattomia VS-lauseita, joissa verbinjälkeinen nominatiivimuotoinen e-subjekti on monikollinen, voidaan pitää sijamerkinnän osalta epäprototyyppisinä eksistentiaalilauseina (vrt. VISK §893): tämän tulkinnan mahdollistaa lauseenalkuinen adverbiaali, jonka jälkeen predikaatti esiintyy melkein aina kolmannessa persoonassa. Vaikka ne ilmaisevat reeman paikalla olevaa uutta referenttiä, nominatiivimuotoinen e-subjekti indikoi tunnistettavaa tarkoitetta sekä sulkeista määrää (tunnistettavuudesta ks. Vilkuna 1992). Esimerkissä (23) tätä tunnistettavuuden määrittämistä auttaa myös relatiivilauseen antama konteksti (ks. tästä myös 4.3). Lauseen (24) adverbiaalilla ratkaisuun on sama rajoittava funktio: kaikista mahdollisista perusteista otetaan huomioon ainoastaan sulkeinen setti juuri siihen ratkaisuun tarkoitettuja perusteita. 
(23) Sieltä löytyy myös sosiaalitilat, jonne kaveriporukka tyttöystävineen kerääntyy viikonlopun viettoon. (KLK_FI_1998)

(24) [...] ratkaisuun löytyi perusteet ulkomaalaislaista. (KLK_FI_1995)

Lause (25) sisältää sekä nominatiivi- että partitiivisubjektin. Nominatiivisubjektin tarkoitteen sulkeismääräisyys on vielä ilmeisempi tässä, jos sitä verrataan partitiivisubjektin ilmaisemaan avomäärään.

(25) Siitä löytyy myös urheiluseurojen ja kylätoimikuntien yhteistiedot sekä joitakin maalaiskunnan nähtävyyksiä. (KLK_FI_1995)

Yhteenvetona sanajärjestys yhdessä (in)kongruenssin kanssa ohjaa monesti lauseen eksistentiaalisuuden tulkintaa. On kiinnostavaa, että definiittisiä ja tarkoitteeltaan tunnistettavia, monikollisia nominatiivisubjekteja esiintyy myös eksistentiaalilauseissa (ks. myös Larjavaara 2019: 185), vaikka kyseisissä konstruktioissa reeman paikka on yleensä varattu yksikön nominatiivissa tai yksikön ja monikon partitiivissa esiintyville uusille, indefiniittisille tarkoitteille.

\subsection{Subjektin sanaluokka ja sanajärjestys}

Subjektin sijamerkintä korreloi subjektin sanaluokan ja sanajärjestyksen kanssa niin, että etenkin pronominisubjektit ovat muita useammin partitiivimuotoisia silloin, kun ne edeltävät verbiä (ks. Kuvion 3 vasen paneeli, y-akseli kuvaa partitiivisubjektin todennäköisyyttä). Muiden kuin substantiiviedussanaisten subjektien pienen määrän vuoksi sen kummemmin sanaluokan ja sanajärjestyksen vuorovaikutus (LRT $\mathrm{X}(3)=2.0077, p=0.5708)$ kuin sanaluokka itsessään $($ LRT $X(6)=4.4454$, $p=0.6166$ ) ei kuitenkaan ole tilastollisesti merkitsevä. On silti huomionarvoista, että etenkin pronominisubjektien (nom=12, part=18) kohdalla eksistentiaalilauseelle ominaisia partitiivisubjekteja on suhteellisesti enemmän kuin substantiiviedussanaisissa subjektilausekkeissa (nom=431, part=297). Toisaalta pronominisubjektit $(\mathrm{SV}=22, \mathrm{VS}=8)$ esiintyvät suhteellisesti substantiiviedussanaisia subjektilausekkeita ( $\mathrm{SV}=350, \mathrm{VS}=374)$ useammin normaalilauseelle tyypillisessä verbinetisessä asemassa. Esimerkit (26)-(29) havainnollistavat aineiston pronominisubjektillisia lauseita niin nominatiivissa kuin partitiivissakin. 
(26) Se löytyy tämän hallituksen kautta. (KLK_FI_1993)

(27) Niitä löytyy myös Sri Lankasta. (KLK_FI_1996)

(28) Varmasti löytyy joku, joka lähtee sitä viljelemään. (KLK_FI_1995)

(29) Löytyykö sitä temppuun ilmoitetulta Santeri Ampujalta? (KLK_FI_1998)

Havainto on mielenkiintoinen sen seikan valossa, että eksistentiaalisten lauseiden subjekteille on havaittu tyypilliseksi se, että ne esittelevät uusia tarkoitteita, joihin ei yleensä viitata toistamiseen. Nämä ominaisuudet ovat tyypillisiä nimenomaan substantiiviedussanaisille subjekteille (Helasvuo 1996, 2001), jotka kuitenkin esiintyvät tässä aineistossa pronominusubjekteja yleisemmin perussubjektille ominaisessa nominatiivissa. Voidaankin kysyä, halutaanko löytyä-lauseiden tulkintaa ohjata eksistentiaaliseksi subjektin sijamerkinnän avulla silloin, kun subjekti on eksistentiaalilauseelle epätyypillinen pronomini. Tätä tulkintaa puoltaa se, että ero näkyy nimenomaan SV-sanajärjestyksellisissä lauseissa, jotka siis niin ikään ovat lähtökohtaisesti epäprototyyppisiä eksistentiaalilauseelle. SV-sanajärjestyksen yleisyys pronominisubjektillisissa löytyä-lauseissa liittynee eksistentiaalilauseen informaatiorakenteeseen: konstruktion teemapaikassa esiintyy todennäköisesti edeltävään kontekstiin viittaava ja siksi tunnettu elementti. Näin ollen lauseen eksistentiaalista tulkintaa ilmaistaan useammin subjektin partitiivisijaisuudella.

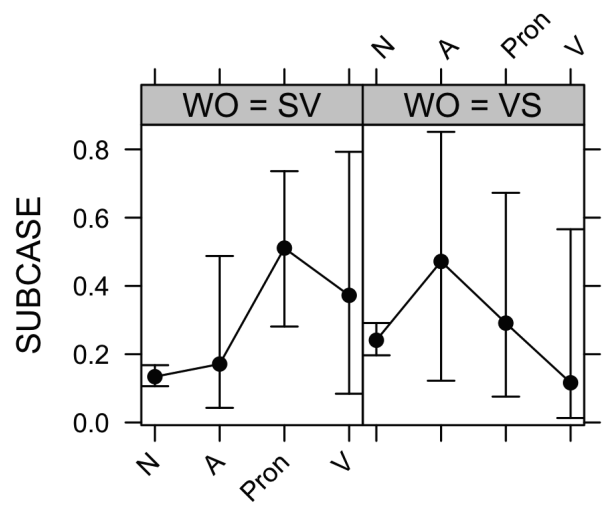

SUBPOS

Kuvio 3. Subjektin sanaluokan ja sanajärjestyksen suhde subjektin sijamerkintään ( $\mathrm{N}=$ substantiivi; $\mathrm{A}=$ adjektiivi; Pron = pronomini; $\mathrm{V}=$ verbi). 
Samalla on kiinnostavaa huomata, kuinka partitiivi vaikuttaa kvantiteettiin pronominien yhteydessä. Esimerkissä (30) relatiivilause määrittää edeltävää pronominia niitä, joka toimii e-subjektina: partitiivi ilmaisee avokvantiteettia, mutta kokonaisuus, johon pronomini viittaa, on sulkeinen joukko.

(30) Aina löytyy niitä, joiden mielestä ruoho on vihreämpää aidan takana. (KLK_FI_1993)

Toisin sanoen kuvitellaan, että on olemassa tietty sulkeinen ryhmä, joka koostuu kaikista ihmisistä, jotka luulevat ruohon olevan vihreämpää aidan takana - partitiivisijaisella pronominilla viitataan moniin kyseiseen ryhmään kuuluviin ihmisiin, jotka koostavat puolestaan toisen indefiniittisen, avoimen joukon. Lauseenalkuinen aika-adverbiaali mahdollistaa lisäksi tilanteen iteratiivisen tulkinnan, joka on tyypillinen niin partitiivisubjekteille kuin eksistentiaalilauseillekin ylipäätään. Seuraavassa alaluvussa pohdimme lisää iteratiivisuudesta sekä muista aspektiin liittyvistä ominaispiirteistä.

\subsection{Aikamuoto}

Myös aikamuodolla on tilastollisesti merkitsevä rooli löytyälauseiden subjektin sijavalinnassa (LRT X(2)=7.5495, $p=0.02294$ ). Kuten Kuvio 4 havainnollistaa, preesensmuotoisten lauseiden subjektit ovat muita aikamuotoja useammin partitiivimuotoisia (y-akseli kuvaa partitiivisubjektin todennäköisyyttä). Tämä on osin odotuksenmukaista: tilanteiden aikarakenne ja subjektin jaollisuus kietoutuvat yhteen (VISK $\S 1522$ ), preteriti on tyypillinen nimenomaan narratiivisessa käytössä, jossa se kuvaa peräkkäisiä, puhehetken kannalta menneitä, määräisiä tapahtumia (VISK §1531; §1538), kun taas preesens kuvaa usein pikemminkin pelkkää olemassaoloa. Aikamuodon voidaan siis katsoa vaikuttavan löytyä-verbin semantiikkaan erityisesti aspektin ja teonlaadun kannalta: preteritillä kuvataan jaotonta tilannetta. Löytyä-verbi on aspektiltaan teelinen ja resultatiivinen sekä yleensä implikoi ennen löytymistä tapahtunutta etsintää, etenkin preteritissä (31) tai perfektissä (32). Sitä voidaan semanttisesti siis pitää koostuvana kahdesta osasta, joista toinen on duratiivinen ja toinen punktuaalinen. 
(31) Etsinnöissä hänen pyöränsä löytyi läheisen koulun pihasta. (KLK_ FI_1995)

(32) Jonkunlainen malli on löytynytkin. (KLK_FI_1996)

On kuitenkin yllättävää, että perfekti näyttää lisäävän nominatiivimuotoisen subjektin todennäköisyyttä - sillä sitä käytetään tyypillisesti ilmaisemaan aspektuaalista imperfektiivisyyttä (VISK §1537). Perfektin osalta ei kuitenkaan ole syytä tehdä kovin pitkälle meneviä johtopäätöksiä, sillä tapausten kokonaismäärä on melko pieni $(\mathrm{n}=38)$.

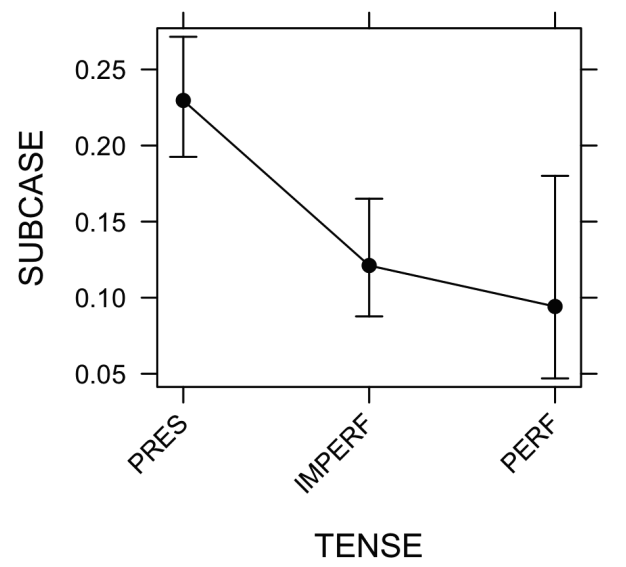

Kuvio 4. Aikamuodon suhde subjektin sijamerkintään.

Aikamuodolla on kiinnostavia vaikutuksia verbi- ja lausesemantiikkaan. Huumon (2003: 477) mukaan partitiivisijainen $e$-theme esiintyy teelisten verbien yhteydessä myös ilman lokatiivista adverbiaalia; toisaalta ateelisten verbien yhteydessä pitää olla lokatiivi (vrt. *Vieraita tanssii; Vieraita tanssii lattialla, ibid.). Hän selittää tämän ilmiön seuraavasti: partitiivisijaiset e-subjektit ohjaavat punktuaalis-iteratiiviseen tulkintaan, jossa yksittäisten referenttien jatkuvaa osallistumista ei edellytetä. Ateelisten verbien kohdalla referenttien on osallistuttava toimintaan jatkuvasti, joten punktuaalis-iteratiivinen tulkinta ei ole mahdollinen; mahdollinen lokatiivinen adverbiaali tarjoaa tulkintaan jonkinlaisen näkökulmapaikan, joka toimii lähtöpisteenä lauseen merkitykselle - mahdollistaen näin partitiivin referenttien ajoittaisen vaihdon. Kun siis otetaan huomioon löytyä-verbin aspektin punktuaalinen osa, 
tämä voi esiintyä iteratiivisessa merkityksessä eikä referenttien osallistuminen ole kontinuatiivista, vaikka lokatiivista adverbiaalia ei olisi (33).

(33) Erojakin toki löytyy. (KLK_FI_2000)

Tässä erojakin-subjektin ymmärretään osallistuvan toimintaan yksi kerrallaan, ja sitä määrää verbin punktuaalinen tulkinta. Toisaalta lause voi myös yksinkertaisesti tarkoittaa, että eroja on olemassa: tästä näkökulmasta katsoen iteratiivisuus ei enää vaikuta lauseen kokonaissemantiikkaan. Kaiken kaikkiaan aikamuoto vaikuttaa löytyä-verbillisten lauseiden tulkintaan suhteessa aspektualisuuden eri tahoihin.

\subsection{Subjektin lemma}

Kuten analyysin alussa toteamme, subjektin lemman sisällyttäminen malliin nostaa sen ennustavuutta selvästi $\left(\mathrm{R}^{2}\right.$ marginaalinen $=0.65$ vs. $\mathrm{R}^{2}$ ehdollinen $=0.73$ ). Vertaamalla lopullista mallia vastaavaan monimuuttujamalliin ilman satunnaismuuttujaa nähdään niin ikään, että tämä ero on tilastollisesti merkitsevä $(\text { LRT X(1) }=5.9604, p=0.01463)^{2}$. Eri sanoilla on siis erilaisia preferenssejä sen suhteen, missä muodossa niitä käytetään löytyä-verbillisten lauseiden subjektina. Taulukko 3 listaa aineiston viisi tyypillisintä nominatiivi- ja partitiivisubjektin lemmaa. Kaikki tyypillisiksi nominatiivisubjekteiksi listatut lemmat esiintyvät aineistossa nominatiivissa vähintään kolme kertaa useammin kuin partitiivissa - ja tyypillisiksi partitiivisubjekteiksi listatut vastaavasti vähintään kolme kertaa useammin partitiivissa kuin nominatiivissa.

Kuten alla olevan Taulukon 3 esimerkit osoittavat, nominatiivisijalle tyypillisten lemmojen tarkoitteet ovat seikkoja, joista ilmaistaan tyypillisesti niiden konkreettista tai metaforista sijaintia, kun taas partitiivisijalle tyypillisten lemmojen tarkoitteet ovat sellaisia, joille on tyypillistä niiden olemassaolon tai -olemattomuuden ilmaiseminen. Tämä vastaa monin tavoin konstruktiokieliopin keskiössä olevaa vuorovaikutusta konstruktion kokonaismerkityksen ja sen osien välillä

2 On osin epäselvää, voiko eri menetelmin sovitettuja tilastollisia malleja verrata yksiselitteisesti keskenään. Käyttämämme glmer-funktion dokumentaatio kuitenkin toteaa seuraavasti: "glmer and glm log-likelihoods are consistent", mistä syystä glmer- ja glmfunktioiden avulla sovitettuja malleja voi nähdäksemme verrata näihin arvoihin perustuvalla uskottavuusosamäärätestillä (engl. likelihood ratio test, LRT). 
(Goldberg, Casenheiser \& Sethuraman 2004). Lisäksi havainto tukee aiempia tutkimuksia lähimerkityksisten konstruktioiden välisen vaihtelun yhteydestä näiden konstruktioiden toisistaan eroaviin leksikaalisiin preferensseihin (Gries \& Stefanowitsch 2004). Nähdäksemme eksistentiaalinen tulkinta korreloi subjektin semantiikan kanssa siten, että tietyt tarkoitteet ohjaavat tulkintaa eksistentiaaliseen suuntaan ja tietyt normaalilauseen suuntaan.

Taulukko 3. Aineiston viisi tyypillisintä nominatiivi- ja partitiivisubjektina esiintyvää lemmaa.

\begin{tabular}{l|l|l|l}
\hline NOM & & PART & \\
\hline $\begin{array}{l}\text { SYY } \\
(10)\end{array}$ & $\begin{array}{l}\text { Syyt kissojen vihaamiseen } \\
\text { löytyvät korvien välistä }\end{array}$ & $\begin{array}{l}\text { TYÖ } \\
(9)\end{array}$ & $\begin{array}{l}\text { Töitä löytyy keittiön } \\
\text { puolelta. }\end{array}$ \\
\hline $\begin{array}{l}\text { RUUMIS } \\
(8)\end{array}$ & $\begin{array}{l}\text { isän ruumis löytyi ratin } \\
\text { takaa }\end{array}$ & $\begin{array}{l}\text { RAHA } \\
(6)\end{array}$ & $\begin{array}{l}\text { palloiluun kyllä löytyy } \\
\text { vain lisää rahaa. }\end{array}$ \\
\hline $\begin{array}{l}\text { MIES } \\
(6)\end{array}$ & $\begin{array}{l}\text { Kuollut mies löytyy } \\
\text { puistonpenkiltä }\end{array}$ & $\begin{array}{l}\text { TIETO } \\
(6)\end{array}$ & $\begin{array}{l}\text { Pankista löytyy siis } \\
\text { tietoja lähes }[. . .]\end{array}$ \\
\hline $\begin{array}{l}\text { PAIKKA } \\
(6)\end{array}$ & $\begin{array}{l}\text { lähin [...] paikka löytyy } \\
\text { [...] kirkonkylästä }\end{array}$ & $\begin{array}{l}\text { TILA } \\
(5)\end{array}$ & $\begin{array}{l}\text { Keskustataajamasta } \\
\text { löytyy kirjastolle tilaa. }\end{array}$ \\
\hline $\begin{array}{l}\text { RATKAISU } \\
(5)\end{array}$ & $\begin{array}{l}\text { Ratkaisu löytyy toisaalta } \\
\text { pienistä avustusten } \\
\text { nousuista. }\end{array}$ & $\begin{array}{l}\text { POIKKEUS } \\
(4)\end{array}$ & $\begin{array}{l}\text { Poikkeuksiakin } \\
\text { ammattikunnasta löytyy. }\end{array}$ \\
\hline
\end{tabular}

\section{Päätelmät}

Tarkastelimme tässä tutkimuksessa löytyä-verbin sisältäviä lauseita niiden subjektijäsenen sijamerkintävaihtelun näkökulmasta. Tutkimuksemme keskiössä oli sijamerkinnän rooli ja vuorovaikutus muiden kielellisten ominaisuuksien kanssa tutkittaessa tällaisten lauseiden asemaa eksistentiaalilauseiden ja normaalilauseiden rajapinnalla. Tuloksemme osoittavat, että erilaiset muuttujat vaikuttavat sijamuotovalintaan subjektin osalta, mutta myös, että ne ovat usein vuorovaikutuksessa keskenään. Voidaan vahvistaa, että subjektin luku on vuorovaikutuksessa subjektin jaollisuuden kanssa: subjektin prototyyppinen jaollisuus lisää partitiivin todennäköisyyttä. Monikossa partitiivi esiintyy todennäköisemmin jaottomien kuin jaollisten subjektien osalta. Monikollisuus 
muuttaa subjektin semanttista kategoriaa, mikä tarkoittaa, että tarkoitteeltaan jaottomasta subjektista tulee kvantiteetiltaan avoin ainoastaan, kun kyseessä oleva monikollinen subjekti on merkitty partitiivilla: tarkoitteeltaan jaollisen subjektin ei tarvitse olla monikossa, jotta avoin kvantiteetti olisi ilmaistu. Päinvastoin, kun jaollinen subjekti esiintyy monikossa, sanan semantiikka muuttuu ja kyseessä on avoin kvantiteetti - esimerkiksi joukko (Larjavaaran 2019: 29 termein "setti") vesiä, mehuja tai suklaita (vrt. sulkeisiin vaihtoehtoihin vedet, mehut, tai suklaat). Sanajärjestys ei ole itsessään tilastollisesti merkitsevä subjektin sijamuotovalinnan kannalta, kun taas kongruenssi on, mikä johtunee siitä, että monikkokongruenssi on partitiivin yhteydessä suorastaan epäkieliopillinen. Niiden vuorovaikutus on myös merkitsevä: subjektin ja verbin välinen inkongruenssi vaikuttaa partitiivin valintaan todennäköisemmin SV-järjestyksellisissä lauseissa. Nämä ovat tärkeitä muuttujia ohjaamassa kohti lauseen eksistentiaalista tulkintaa. Vaikka subjektin sanaluokka ei vaikuta tilastollisesti merkitsevältä, kun se on vuorovaikutuksessa sanajärjestyksen kanssa, huomasimme, että nominatiivisubjekteja on enemmän substantiivien joukossa, sillä ne tyypillisesti esittävät uusia tarkoitteita, kun taas pronominit viittaavat aiemman mainittuun tai ylipäätään jo tiettyyn tarkoitteeseen. VS-järjestys lisää partitiivin todennäköisyyttä substantiivien kanssa. Myös aikamuodon ja subjektin sijamerkinnän välillä on tilastollisesti merkitsevä yhteys: preesens esiintyy partitiivin kanssa useammin kuin menneisyyteen viittaavat aikamuodot, sillä niiden kuvailemat menneet tapahtumat voidaan katsoa määräisiksi, puhujalle/kirjoittajalle jo tietyiksi. Menneen ajan muodoista perfekti esiintyy nominatiivissa preteritiä useammin, mutta havaintojen suhteellisen pieni määrä ei oikeuta tilastollisesti merkitsevien tulkintojen tekoon. Subjektin lemma on myös tilastollisesti merkitsevä, sillä tietyt sanat esiintyvät erityisesti normaalilauseen subjekteina niin, että lause ilmaisee niiden tarkoitteiden sijaintia, kun taas toiset sanat suosivat konteksteja, joissa kuvataan niiden olemassaoloa ylipäätään.

On edelleen epäselvää, mikä normaali- ja eksistentiaalilauseen välinen raja on monissa tapauksissa, mutta tutkimuksemme osoittaa, että valitsemiemme eri muuttujien välillä on vuorovaikutteinen suhde. Löytyä-verbillisten lauseiden konstruktio ei siis ole määriteltävissä ainoastaan sanajärjestyksen tai verbin ja subjektin välisen kongruenssin pohjalta. Jokaisella muuttujalla on oma vaikutuksensa subjektin sijamuodon valitsemiseen, ja nämä tekijät yhdessä ohjaavat yksittäisten 
lauseiden tulkintaa enemmän tai vähemmän eksistentiaalisuutta ilmaisevaan suuntaan. Nähdäksemme tämä vastaa konstruktiokieliopin näkemystä siitä, että kunkin konstruktion sisäisessä vaihtelussa sen prototyyppisimmät variantit ovat myös lähinnä konstruktiomerkityksen mukaista tulkintaa (Goldberg, Casenheiser \& Sethuraman 2004). On kiinnostavaa havaita, että riippumatta analysoiduista muuttujista usein nominatiivi- ja partitiivisubjektin vaihtelu johtaa juuri sulkeis- tai avokvantiteetin tulkintaan. Subjektin sijamuoto muuttaa tarkoitteen kvantiteettia, jolla on vaikutus lauseen informaatiorakenteeseen, minkä voi huomata subjektin jaollisuuden, sanajärjestyksen sekä subjektin sanaluokan vuorovaikutteisesta suhteesta.

Semantiikan näkökulmasta löytyä-verbi korvaa monesti olla-verbin ja on tästä syystä kiinnostava verrattuna muihin suomenkielisissä eksistentiaalilauseissa esiintyviin verbeihin. Tämä semanttinen haalistuminen näkyy erityisesti prototyyppisissä eksistentiaalilauseissa, joissa uusi referentti tuodaan "puhtaasti" esiin: tässä käyttöyhteydessä verbi voi kongruoida subjektin kanssa ja subjektin sijamuotovalinnalla ei ole niin tärkeä rooli, kun taas on tarpeellista, että lokatiiviadverbiaali on lauseen alussa. Normaalilauseissa, eli yleensä kun lauseen subjekti on nominatiivissa ja sanajärjestys on suora (SV), löytyä-verbin semantiikka voi tietysti sisältää aspektuaalisia sävyjä kuten iteratiivisuutta tai viitata edeltävään, duratiiviseen etsintäprosessiin. Yleinen tendenssi sekä normaalilauseissa että eksistentiaalilauseissa on joka tapauksessa se, että näitä aspektuaalisia sävyjä ei säilytetä. Tämä näkyy esimerkiksi sellaisissa partitiivitapauksissa, joissa tulkinta on kollektiivinen. On kiinnostavaa huomata, että lokatiiviadverbiaalin olemassaolo ei sanajärjestyksestä riippumatta monesti vähennä löytyä-verbin semanttista haalistumista, vaikka sen suuntaisuus saattaa viitata jotenkin kompleksisempaan semantiikkaan.

Yhtenä tämän tutkimuksen kannalta kiinnostavista uusista tutkimussuunnista olisi kääntää tutkimusasetelma osin päinvastaiseksi: mitkä verbit ylipäätään mahdollistavat partitiivisubjektin käytön? Olisi niin ikään mielenkiintoista paneutua syvemmin partitiivissa esiintyvien subjektien tyypillisiin semanttisiin piirteisiin. Nähdäksemme tutkimuksessamme käytetyt menetelmät soveltuvat hyvin näiden kysymysten tarkasteluun. Regressioanalyysin avulla tarkasteltavaan ilmiöön samanaikaisesti vaikuttavat useat muuttujat voidaan vakioida niin, että niistä kutakin voidaan tarkastella erikseen ja vuorovaikutuksessa toistensa 
kanssa ilman, että eri muuttujien vaikutukset peittävät alleen tai muuttavat toinen toisiaan. Me toivommekin tämän tutkimuksen kannustavan partitiivisubjektin mahdollistavien verbien ja tällaisten subjektien tyypillisten semanttisten piirteiden selvittämiseen jatkossa.

\section{Lähteet}

Bartoń, Kamil. 2018. MuMIn: Multi-Model Inference. https://cran.r-project.org/web/ packages/MuMIn/.

Bates, Douglas, Martin Mächler, Ben Bolker \& Steve Walker. 2015. Fitting linear mixed-effects models using lme4. Journal of Statistical Software 67(1). 1-48. https://doi.org/10.18637/jss.v067.i01.

Bentley, Delia, Francesco Maria Ciconte \& Silvio Cruschina. 2013. Existential constructions in crosslinguistic perspective. Italian Journal of Linguistics 25(1). 15-43.

Blaszczak, Joanna. 2009. Differential subject marking in Polish: The case of genitive vs. nominative subjects in ' $\mathrm{X}$ Was Not at $\mathrm{Y}$ '-constructions. Helen de Hoop \& Peter de Swart (toim.), Differential subject marking, 113-149. Dordrecht: Springer. https:// doi.org/10.1007/978-1-4020-6497-5_6.

Błaszczak, Joanna. 2012. A spurious genitive puzzle in Polish. T. Hanneforth \& G. Fanselow (toim.), Language and logos (Studia Grammatica 72), 17-47. Berlin: Akademie Verlag. https://doi.org/10.1524/9783050062365.17.

Breivik, Leiv Egil. 1999. On the rhetorical function of existential there. Nordlit. 3-14. https://doi.org/10.7557/13.2125.

Creissels, Denis. 2014. Existential predication in typological perspective. Ms., Université Lyon. http://www.deniscreissels.fr/public/Creissels-Exist.Pred.pdf. (14.6.2021.)

Cruschina, Silvio. 2012. Focus in existential sentences. Valentina Bianchi \& Cristiano Chesi (toim.), Enjoy linguistics! Papers offered to Luigi Rizzi on the occasion of his 60th birthday, 77-107. Siena: CISCL Press.

Fox, John \& Jangman Hong. 2009. Effect displays in $R$ for multinomial and proportional-odds logit models: Extensions to the effects package. Journal of Statistical Software 32(1). 1-24. https://doi.org/10.18637/jss.v032.i01.

Goldberg, Adele E. 1995. Constructions: A construction grammar approach to argument structure (Cognitive Theory of Language and Culture). Chicago: University of Chicago Press.

Goldberg, Adele E. 2006. Constructions at work: The nature of generalization in language. Oxford: Oxford University Press.

Goldberg, Adele, Devin Casenheiser \& Nitya Sethuraman. 2004. Learning argument structure generalizations. Cognitive Linguistics 15(3). 289-316. https://doi. org/10.1515/cogl.2004.011.

Gries, Stefan Th. 2015. The most under-used statistical method in corpus linguistics: Multi-level (and mixed-effects) models. Corpora 10(1). 95-125. https://doi. org/10.3366/cor.2015.0068. 
Gries, Stefan Th. \& Stefanie Wulff. 2013. The genitive alternation in Chinese and German ESL learners: Towards a multifactorial notion of context in learner corpus research. International Journal of Corpus Linguistics 18(3). 327-356. https://doi. org/doi:10.1075/ijcl.18.3.04gri.

Gries, Stefan Th. \& Anatol Stefanowitsch. 2004. Extending collostructional analysis: A corpus-based perspective on 'alternations'. International Journal of Corpus Linguistics 9(1). 97-129. https://doi.org/10.1075/ijcl.9.1.06gri.

Hakanen, Aimo. 1972. Normaalilause ja eksistentiaalilause. Sananjalka 14(1). 36-76. https://doi.org/10.30673/sja.86366.

Hashemi, Mohammad R. 2012. Reflections on mixing methods in applied linguistics research. Applied Linguistics 33(2). 206-212. https://doi.org/10.1093/applin/ams008.

Helasvuo, Marja-Liisa. 1996. Ollako vai eikö olla - eksistentiaalilauseen subjektin kohtalonkysymys. Virittäjä 100(3). 340-356.

Helasvuo, Marja-Liisa. 2001. Syntax in the making: The emergence of syntactic units in Finnish conversation (Studies in Discourse and Grammar 9). Amsterdam/ Philadelphia: John Benjamins. https://doi.org/10.1075/sidag.9.

$\mathrm{Hu}$, Jianhua \& Haihua Pan. 2008. Focus and the basic function of Chinese existential you-sentences. Ileana Comorovski \& Klaus von Heusinger (toim.), Existence: Semantics and syntax, 133-145. Dordrecht: Springer. https://doi.org/10.1007/9781-4020-6197-4_5.

Huumo, Tuomas. 2003. Incremental existence: The world according to the Finnish existential sentence. Linguistics 41(3). 461-493. https://doi.org/10.1515/ling.2003.016.

Huumo, Tuomas. 2006. Kvantiteetti ja aika I. Nominaalisen aspektin näkökulma suomen objektin ja subjektin sijamerkintään. Virittäjä 110(4). 504-538.

Huumo, Tuomas \& Marja-Liisa Helasvuo. 2015. On the subject of subject in Finnish. Marja-Liisa Helasvuo \& Tuomas Huumo (toim.), Subjects in constructions canonical and non-canonical (Constructional Approaches to Language 16), 13-41. Amsterdam: John Benjamins. https://doi.org/10.1075/cal.16.02huu.

Huumo, Tuomas \& Liina Lindström. 2014. Partitives across constructions: On the range of uses of the Finnish and Estonian 'partitive subjects'. Silvia Luraghi \& Tuomas Huumo (toim.), Partitive cases and related categories. Berlin, Boston: De Gruyter. https://doi.org/10.1515/9783110346060.153.

Ikola, Osmo. 1954. Suomen lauseopin ongelmia [I-III]. Virittäjä 58(3). 209-244.

Ivaska, Ilmari. 2010. Eksistentiaalilauseen subjektijäsen edistyneiden suomenoppijoiden kirjoituksessa. Sananjalka 52. 67-88. https://doi.org/10.30673/sja.86697.

Ivaska, Ilmari. 2011. Lausetyyppien sekoittuminen edistyneessä oppijansuomessa näkökulmana eksistentiaalilause. Lähivőrdlusi. Lähivertailuja 21. 65-85. https:// doi.org/10.5128/lv21.03.

Klavan, Jane. 2020. Pitting corpus-based classification models against each other: a case study for predicting constructional choice in written Estonian. Corpus Linguistics and Linguistic Theory 16(2), 363-391. https://doi.org//10.1515/cllt-2016-0010.

Langacker, Ronald W. 2008. Cognitive grammar. Berlin: De Gruyter Mouton. https:// doi.org/10.1515/9783110199901.29.

Larjavaara, Matti. 1988. Suomen kvantitatiivinen spesies. Virittäjä 92(4). 469-503. 
Larjavaara, Matti. 2019. Partitiivin valinta. Helsinki: Suomalaisen Kirjallisuuden Seura. Lees, Aet. 2015. Case alternations in five Finnic languages: Estonian, Finnish, Karelian, Livonian and Veps. Leiden: Brill. https://doi.org/10.1163/9789004296367. Lindström, Liina. 2017. Partitive subjects in Estonian dialects. Eesti ja soome-ugri keeleteaduse ajakiri. Journal of Estonian and Finno-Ugric Linguistics 8(2). 191231. https://doi.org/10.12697/jeful.2017.8.2.07.

Luraghi, Silvia \& Seppo Kittilä. 2014. Typology and diachrony of partitive case markers. Silvia Luraghi \& Tuomas Huumo (toim.), Partitive cases and related categories (Empirical Approaches to Language Typology 54), 17-62. Berlin, Boston: De Gruyter Mouton. https://doi.org/10.1515/9783110346060.17.

McNally, Louise. 2016. Existential sentences crosslinguistically: Variations in form and meaning. Annual Review of Linguistics 2. 211-231. https://doi.org/10.1146/ annurev-linguistics-011415-040837.

Milsark, Gary L. 2014. Existential sentences in English (RLE Linguistics D: English Linguistics). London: Routledge. https://doi.org/10.4324/9781315856728.

Partee, Barbara H. \& Vladimir Borschev. 2008. Existential sentences, BE, and the genitive of negation in Russian. Ileana Comorovski \& Klaus von Heusinger (toim.), Existence: Semantics and syntax, 147-190. Dordrecht: Springer. https://doi. org/10.1007/978-1-4020-6197-4_6.

R Core Team. 2018. R: A Language and Environment for Statistical Computing. Vienna, Austria: R Foundation for Statistical Computing. https://www.R-project.org/.

Sawyer, Janet. 1973. Existential sentences: A linguistic universal? American Speech 48(3/4). 239-245. https://doi.org/10.2307/3087831.

Seržant, Ilja A. 2014. The independent partitive genitive in North Russian. Björn Wiemer \& Ilja Seržant (toim.), Contemporary approaches to dialectology: the area of North, Northwest Russian and Belarusian vernaculars (Slavica Bergensia 12), 270-329. Bergen: University of Bergen.

Stefanowitsch, Anatol \& Stefan Th. Gries. 2003. Collostructions: Investigating the interaction of words and constructions. International Journal of Corpus Linguistics 8(2). 209-43. https://doi.org/10.1075/ijcl.8.2.03ste.

Vilkuna, Maria. 1992. Referenssi ja määräisyys suomenkielisten tekstien tulkinnassa (Suomi 163). Helsinki: Suomalaisen Kirjallisuuden Seura.

VISK = Hakulinen, Auli, Maria Vilkuna, Riitta Korhonen, Vesa Koivisto, Tarja Riitta Heinonen \& Irja Alho. 2004. Iso suomen kielioppi. Helsinki: Suomalaisen Kirjallisuuden Seura. Verkkoversio. http://scripta.kotus.fi/visk (4.3.2020).

Ward, Gregory. 1999. A comparison of postposed subjects in English and Italian. Akio Kamio \& Ken-ichi Takami (toim.), Function and structure: Studies in honor of Susumu Kuno, 3-21. Amsterdam: John Benjamins. https://doi.org/10.1075/ pbns.59.03war.

Winter, Bodo. 2020. Statistics for linguists: An introduction using R. London: Routledge. https://doi.org/10.4324/9781315165547. 


\begin{abstract}
Rodolfo Basile, Ilmari Ivaska: Subject case alternation in constructions containing the Finnish verb löytyä. This article examines the nominative-partitive subject alternation occurring with constructions containing the Finnish verb löytyä. The material used is taken from corpora and consists of a random sample of 779 observations, analyzed both quantitatively by means of statistical methods, and from a qualitative point of view. The research aims at investigating which variables influence the case alternation of subjects of constructions containing the verb löytyä. The chosen variables are subject number, subject divisibility, subject part of speech, word order, tense, agreement and subject lemma, the only random variable. With the help of regression analysis, the subject case is predicted on the basis of said variables and of interactions between them. The qualitative analysis will also discuss the relationship these morphosyntactic and semantic variables have with the existential interpretations of the clause as well as with the subject quantity and definiteness.
\end{abstract}

Keywords: subject alternation, partitive, constructions, morphosyntax, regression analysis, quantitative research, corpus linguistics, Finnish language

\begin{abstract}
Kokkuvõte. Rodolfo Basile, Ilmari Ivaska: Subjekti käändevaheldus löytyä-verbiga konstruktsioonides. Artiklis uuritakse nominatiivi- ja partitiivikujulise subjekti vaheldumist soome keele löytyä-verbi sisaldavates konstruktsioonides. 779 vaatlust sisaldavat korpustest pärinevat juhuvalimit analüüsitakse nii kvantitatiivsete kui ka kvalitatiivsete meetoditega. Uurimuse eesmärk on välja selgitada, millised tegurid löytyä-verbi sisaldavate konstruktsioonide subjekti käändevalikut mõjutavad. Käsitletavad tegurid on subjekti arv, loendatavus, sõnaliik, konstruktsiooni sõnajärg, ajavorm ning subjekti ja verbi ühildumine. Juhusliku muutujana kaasatakse ka subjekti lemma. Regressioonanalüüsi abil ennustatakse subjekti käändevalikut mainitud tegurite ja nendevaheliste koosmõjude kaudu. Kvalitatiivse analüüsi käigus arutletakse ka selle üle, milline on nimetatud morfosüntaktiliste ja semantiliste tegurite mõju lause eksistentsiaalsele tõlgendusele ning subjekti kvantiteedile ja definiitsusele.
\end{abstract}

Märksõnad: subjekti käändevaheldus, partitiiv, konstruktsioonid, morfosüntaks, regressioonanalüüs, kvantitatiivne uurimus, korpuslingvistika, soome keel 